\title{
FOREIGN BODY IN THE EXTENSOR TENDON SHEATH
}

\author{
EKSTANSÖR TENDON KILIFINDAKİ YABANCI CİSİM: Olgu sunumu
}

\author{
Azimet ÖZDEMİ, Selma SÖNMEZ ERGÜN, Mehmet Veli KARAALTIN, Kemalettin \\ YILDIZ, Çetin DUYGU*
}

\begin{abstract}
Foreign body is rarely seen in tendon sheaths. An unusual case of embedded metallic foreign body in the right extensor pollicis longus tendon sheath that induced symptoms mimicking De-Quervain's disease was cured after surgical removal of the foreign body and reported here.

Key words: Foreign body; extensor tendon sheath.
\end{abstract}

\section{ÖZET}

Yabancı cisimler tendon kılıflarında nadiren görülürler.

Bu çalışmada, De-Quervain hastalığı semptomlarına yol açan ve cerrahi girişimle sağ ekstansör pollicis longus tendon kılıfına gömülen metalik yabancı cismin çıkarılmasıyla tedavi edilen olgu sunulmaktadır.

Anahtar kelimeler: Yabancı cisim, ekstansör tendon kılıfı.

\section{INTRODUCTION}

De Quervain's disease is the stenosing tenosynovitis of the first dorsal compartment of the wrist. Patients mostly experience radial sided wrist pain exacerbated by activity requiring thumb extension or abduction, or wrist motion in ulnar plane. Focal tenderness and swelling may be observed over the radial styloid and the first dorsal compartment (7).

Sharp, localized pain with palpation over a puncture wound or limited passive range of motion of a joint near a wound may indicate a retained foreign body $(2,5,6)$.

Tenosynovitis secondary to penetrating plant thorn injury is rarely reported in the literature (1). A foreign body located in an extensor tendon of the thumb might cause symptoms that mimic De Quervain's disease is not reported in the literature.

\section{CASE REPORT}

A 37-year-old steel-worker male patient admitted to our hospital with complaints of tenderness and pain at the base of the right thumb. History of the patient revealed a previous minor trauma of the right hand that a small steel bar had hit his hand two years ago.
On physical examination, a triggering pain was observed during the extension of the right thumb. Pain was aggravated by the Finkelstein's test.

Clinically stenosing tenosynovitis was considered in the primary diagnosis, but anteroposterior and lateral radiographs of the hand revealed a foreign body at the base of the thumb (Fig.1 a,b).

Operation was planned under local anesthesia for the removal of foreign body. A lazy S incision located on the dorsal metacarpal level was performed, and then, third extensor compartment sheath was incised longitudinally. $3 \mathrm{cc}$ of synovial fluid was aspirated.

When the extensor pollicis longus tendon (EPL) was retracted, a dark colored, round metal piece was found in the EPL tendon sheath (Fig. 2). The foreign body was removed by delicate dissection. The fibroosseous sheath and skin were properly closed. After dressing, cast was used for immobilization. Cast was removed on the third postoperative week, and the thumb had a full range of motion with no complaint of pain.

\footnotetext{
Date received/Dergiye geldiği tarih: 21.03.2014 - Dergiye kabul edildiği tarih: 05.08.2014

*Department of Plastic, Reconstructive and Aesthetic Surgery, Bezmialem Faculty of Medicine, Bezmialem Vakif University, Istanbul-TURKEY

(İletişim kurulacak yazar: selmasonmezergun@yahoo.com)
} 


\section{Ekstansör tendondaki yabancı cisim}

Figure 1 a,b: Radiographic views of the patient's right hand. Note the foreign body at the base of first metacarpus.
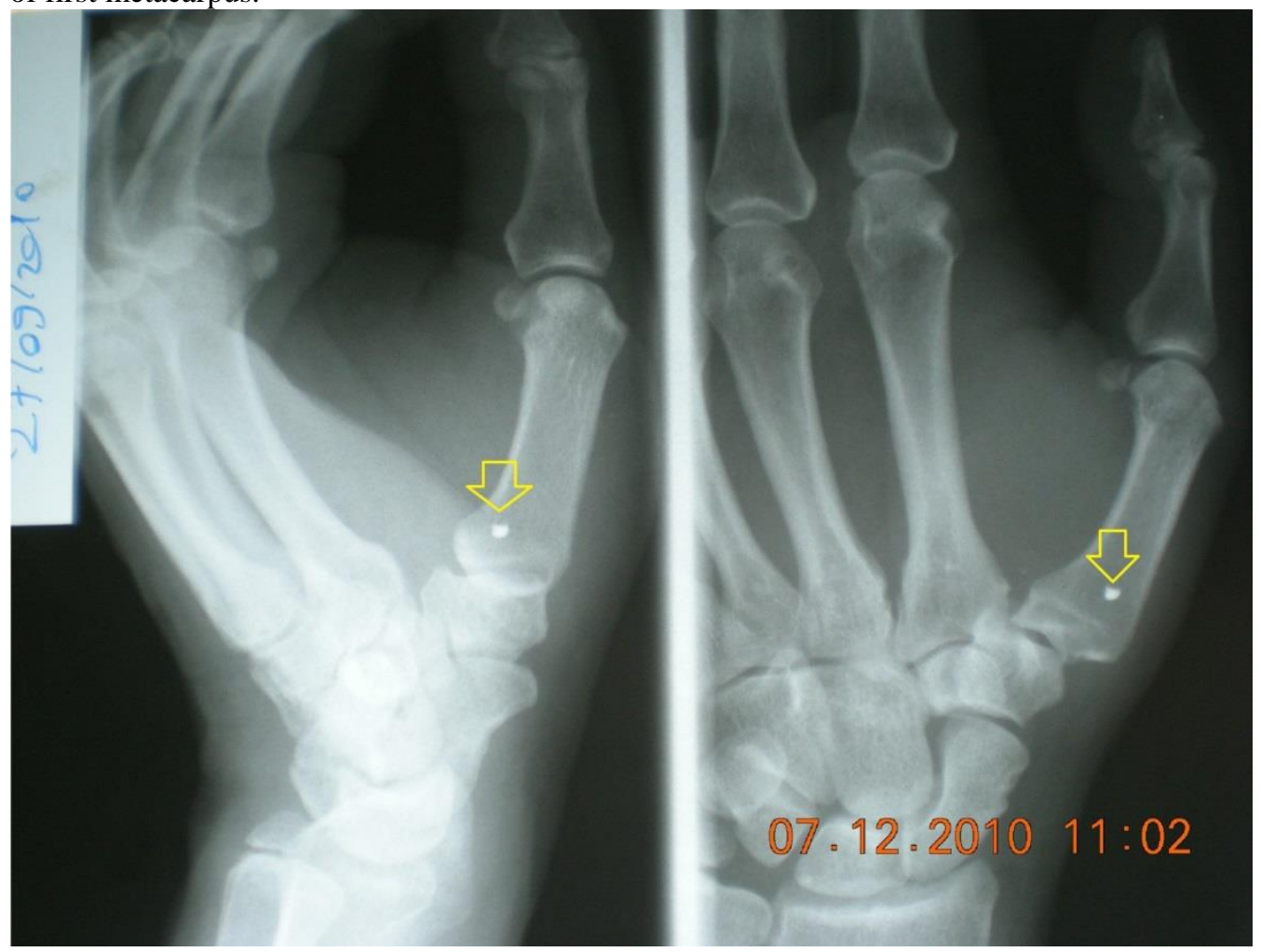

Figure 2a,b: Intraoperative appearances of the embedded foreign body in the tendon sheath.

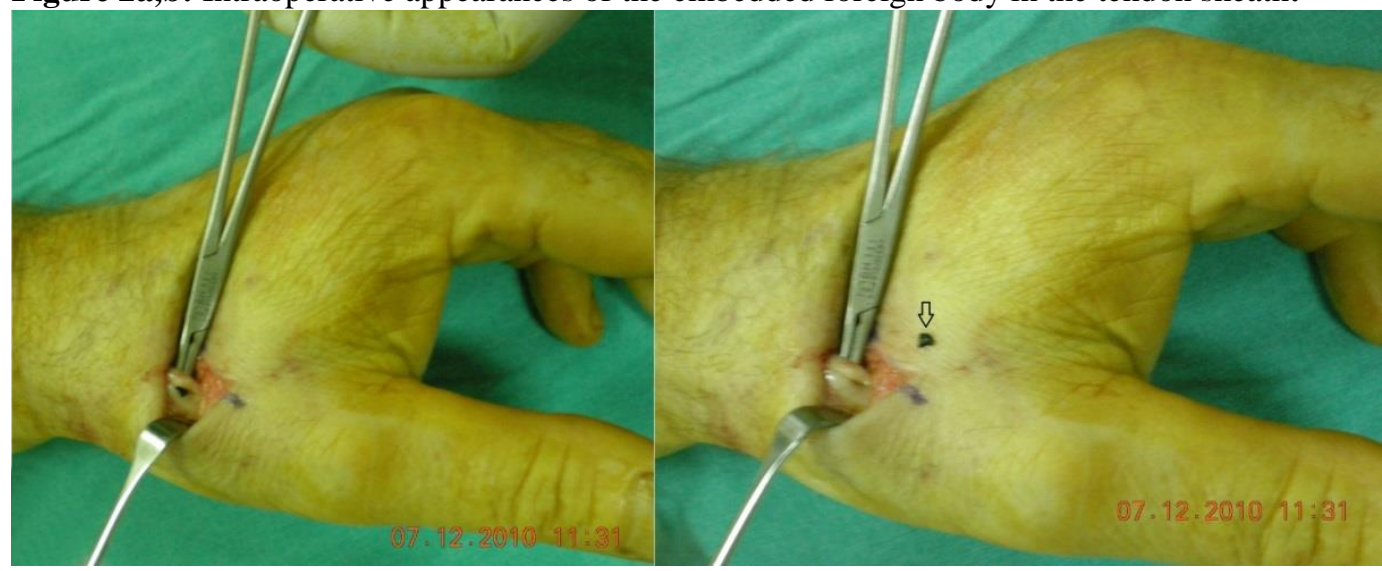

\section{DISCUSSION}

Foreign bodies may incite a variety of soft tissue infections, including local wound infection, cellulitis, abscess formation, lymphangitis, tenosynovitis, bursitis, and osteomyelitis. A foreign body rarely remains within a tendon sheath for prolonged time. In such cases, delay of the diagnosis occurs due to forgotten preceding injury. Therefore, complete medical history should be obtained. Imaging may be helpful to localize the metallic implant material when the history is not clear $(1,2,4,5,6)$.

The size of the foreign body, moreover its anatomic location might determine clinical manifestations. A big foreign body cannot remain inside a synovial sheath, because it destroys the sheath and displaces into the surrounding tissues. Whereas a small foreign body may enter into the sheath of a tendon at the time that the puncture wound occurs, or it may work its way into the sheath from the adjacent tissues as a result of chronic inflammation and erosion of the sheath (6).

De-Quervain's disease results from stenosing tenosynovitis of the first dorsal compartment of the wrist or due to an offending bony pathology of the radial styloid process. Patients experience progressive pain, tenderness and swelling at the radial side of the wrist with limitations of motions occurring in activities of the affected hand. Intrusion of a foreign body to the hand rarely may cause annoying problems such as pain and tenderness that might interfere with quality of life $(3,7)$.

Although the foreign body is located more distally in our case, it induced symptoms that mimic De Quervain's disease. 


\section{Foreign body in the extensor tendon}

The decision to remove a deeply embedded foreign body depends on the object's size, location, composition, accessibility and any expected mechanical and inflammatory effects. However, most foreign bodies in the hands should be removed due to the potential risk of nerve and tendon injury. The proper approach for deeply embedded foreign bodies should include adequate anesthesia, a bloodless field, proper retracting of the wound edges and spreading deeper tissues for an extensive visualization $(8,9)$.

In conclusion, patient's history and laboratory-imaging results should be considered to get a good clue for the primary diagnosis of foreign body injuries. Foreign bodies in extensor tendons of the thumb should be included in the differential diagnosis of De-Quervain's disease.

\section{REFERENCES}

1. Baskar S, Mann JS, Thomas AP, Newton P. Plant thorn tenosynovitis. J Clin Rheumatol 2006;12: 137 138.

2. Chan JK, Lamyman M, Heywood A. Foreign body migration within the flexor sheath. J Hand Surg Eur Vol. 2010; 35:595-7.

3. Chien AJ, Jacobson JA, Martel W, Kabeto MU, Marcantonio DR. Focal radial styloid abnormality as a manifestation of de Quervain tenosynovitis. AJR Am J Roentgenol. 2001;177:1383-6.

4. Howden MD. Foreign bodies within finger tendon sheaths demonstrated by ultrasound: two cases. Clin Radiol 1994; 49:419-20.

5. Morris L, Stevens A, Doherty M. Chronic flexor tenosynovitis: missed diagnosis for a decade. Ann Rheum Dis 1996; 55:597-9.

6. Rida A. A foreign body in a tendon sheath. J Bone Joint 1961; 43-A:282-3.

7. Seyhan H, Kopp J, Horch R. De Quervain's stenosing tendovaginitis, one of the most common conditions affecting the hand. MMW Fortschr Med. 2006;148:33-5.

8. Yang SS, Bear BJ, Weiland AJ. Rupture of the flexor pollicis longus tendon after 30 years due to migration of a retained foreign body. J Hand Surg $\mathrm{Br}$ 1995; 20:803-805.

9. Tuncer S, Ozcelik IB, Mersa B, Kabakas F, Ozkan T. Removal of glass fragments from hand injuries. Ann Plas Surg 2011; 67:114-8. 